Gastrointestinal parasites of zoonotic importance observed in the wild, urban, and captive populations of non-human primates in Malaysia

Article in Journal of Medical Primatology · October 2018

DOI: $10.1111 / \mathrm{jmp} .12389$

CITATIONS

0

5 authors, including:

2

Madinah Adrus

University Malaysia Sarawak

22 PUBLICATIONS 41 CITATIONS

SEE PROFILE

Jayasilan Mohd-Azlan

University Malaysia Sarawak

79 PUBLICATIONS 607 CITATIONS

SEE PROFILE
READS

108

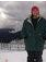

Ramlah bt Zainudin

University Malaysia Sarawak

53 PUBLICATIONS 104 CITATIONS

SEE PROFILE

MT Abdullah

Universiti Malaysia Terengganu

324 PUBLICATIONS 721 CITATIONS

SEE PROFILE

Some of the authors of this publication are also working on these related projects:

cave bat View project

Biodiversity Survey and Vertical Stratification Study in Peninsular Malaysia East-Coast Region View project 


\title{
Gastrointestinal parasites of zoonotic importance observed in the wild, urban, and captive populations of non- human primates in Malaysia
}

\author{
Madinah Adrus $^{1}$ (D) | Ramlah Zainudin ${ }^{1}$ | Mariana Ahamad ${ }^{2}$ | Mohd-Azlan Jayasilan ${ }^{1}$ \\ Mohd Tajuddin Abdullah ${ }^{3}$
}

\begin{tabular}{|c|c|c|c|}
\hline Animal & Resource & Science & and \\
\hline \multicolumn{2}{|c|}{ Management } & \multicolumn{2}{|c|}{ Programme, Faculty of } \\
\hline \multicolumn{4}{|c|}{ Resource Science and Technology, Universiti } \\
\hline \multicolumn{4}{|c|}{ Malaysia Sarawak } \\
\hline (UNIMAS), & Kota & \multirow{2}{*}{\multicolumn{2}{|c|}{ Samarahan, Sarawak, }} \\
\hline IVIalaysla & & & \\
\hline${ }^{2}$ Unit & of & Acarology, & Infectious \\
\hline \multicolumn{4}{|l|}{ Diseases } \\
\hline \multicolumn{4}{|c|}{ Research Centre, Institute for Medical } \\
\hline Research, & Kuala & Lumpur, & Malaysia \\
\hline 3Kenyir & Research & Institute, & Universiti \\
\hline Malaysia & Terenggan & , Kuala & Terengganu, \\
\hline \multicolumn{4}{|c|}{ Terengganu, Malaysia } \\
\hline \multicolumn{4}{|c|}{ Correspondence } \\
\hline $\begin{array}{l}\text { Madinah } \\
\text { Science }\end{array}$ & $\begin{array}{l}\text { Adrus, } \\
\text { and Manag }\end{array}$ & $\begin{array}{l}\text { Animal } \\
\text { ement Progra }\end{array}$ & $\begin{array}{l}\text { Resource } \\
\text { amme, Facult }\end{array}$ \\
\hline \multicolumn{4}{|c|}{ of Resource Science and Technology, Universiti } \\
\hline Malaysia & Sarawak & (UNIMAS), & Kota \\
\hline $\begin{array}{l}\text { Samarahan } \\
\text { amadinah }\end{array}$ & $\begin{array}{l}\text { arawak, } M \\
\text { nimas.my }\end{array}$ & laysia. Email & \\
\hline
\end{tabular}

\begin{abstract}
Background: A study was undertaken to determine gastrointestinal (GI) parasites commonly found in Malaysia's non- human primates (NHP) living in three different types of populations (wild, urban, and captive) and the basis of major GI parasites of zoonotic importance.

Methods:

A total of 308

samples was

collected and microscopically

screened from

the NHP in the wild ( $n=163)$, urban $(n=76)$, and captive $(n=69)$ populations. The samples were taken from 12 species of local NHPs.

Results: At

$\begin{array}{llll}\text { least, } 44 & \text { species of } & \text { parasites comprising } \\ \text { of } & \text { (seven species), nematodes (26 species), }\end{array}$
\end{abstract}

cestodes (five species), trematodes (five species), and pentastomida (one species) were detected. There were no significant differences for the overall prevalence and no great differences in GI parasite species among the wild, urban, and captive NHP populations.

Conclusion: The most common GI parasite was Ascaris spp. (49.7\%), followed by Oesophagostomum spp. (26.9\%), and 31 species discovered in this study are of known public health importance.

KEYWORDS

emerging infectious diseases, gastrointestinal parasites, infection, non-human primates, zoonotic 